\title{
Connecting Household History and Labour History
}

\section{MARCEL VAN DER LINDEN}

Labour historians have always shown an interest in working class men and women who participated in strikes, unions, and political parties. However, even when historians are receptive to the importance of family life behind public activism these scholars continue to use the "public sphere" as an approach for studying the family. ${ }^{1}$ This approach runs counter to historical logic because the daily life of those who join social movements and organizations involves far more than merely labour activism. To understand the true causes of collective resistance among workers, it is necessary to use the "private sphere" as an approach for studying labour protests as well. While this reverse perspective may not prove a panacea for all problems associated with analysing labour history, it will provide insight into the rather obscure motives of the working class for deciding whether or not to support the development of workers' movements. Furthermore, Jean $\mathrm{H}$. Quataert wrote that examining working-class households makes it possible to keep "in focus at all times the lives of both men and women, young and old, and the variety of paid and unpaid work necessary to maintain the unit".

To the best of my knowledge there has been no systematic effort to establish a link between working-class families and labour movements. While this short paper is by no means an exhaustive discussion of this unexplored field, it does attempt to examine the relationship between labour activism and other strategies for survival and improvement in working-class households.

\section{Principles}

Up to this point I have used "families" and "households" interchangeably. The meanings of these terms, however, are not identical, as kinship forms the primary basis for families, whereas households are mainly economic units based on income pooling. The present paper is about households.

\footnotetext{
I For essays using this approach that are excellent in many other respects, see Harold Benenson's "The Community and Family Bases of U.S. Working Class Protest, 1880-1920: A Critique of the 'Skill Degradation' and 'Ecological' Perspectives", Research in Social Movements, Conflicts and Change, 8 (1985), pp. 109-132, and Bruce Scates' "Gender, Household and Community Politics: The 1890 Maritime Strike in Australia and New Zealand", Labour Hislory, 61 (1991), pp. 70-87.

2 Jean H. Quataert, "Combining Agrarian and Industrial Livelihood: Rural Households in the Saxon Oberlausitz in the Nineteenth Century", Joumal of Family History, 10 (1985), pp. 145-162, 158.
}

International Review of Social History 38 (1993), pp. 163-173 
This concept is rather ambiguous and has been subject to extensive terminological debates. ${ }^{3}$ To avoid a digression into this issue, I will use the description in McGuire et al., which states that households are "those sets of relationships, historically variable yet relatively constant, that have as one of their principal features the sharing of sustenance gained from the widest possible variety of sources". 4 This description is loose enough to cover a wide variety of situations. It stresses the budget-pooling aspect of households, an approach that serves the purpose of my project.

The following reservations apply to using the designation of households:

(i) Households do not necessarily consist of two or three generations of one family. They may include several families, other types of biological kinship (such as siblings), or members not related by blood or marriage. (ii) Households do not necessarily entail co-residence, not even according to Donald Bender's definition that calls for "a proximity in sleeping arrangements and a sentiment similar to that expressed in our folk concept of home". 5 For example, at least one member in a household of seasonal migrants is likely to live elsewhere for months at a time and will nevertheless contribute substantially to the household budget. (In the absence of co-residence, it is possible to form what I will call secondary households.) ${ }^{6}$

(iii) The focus on economic aspects should not diminish the role of households as culturally significant units shaped by symbolic processes. ${ }^{7}$ (iv) Rather than being predetermined, the composition of households is a product of negotiations. Factors affecting the composition of a household may include income, marriage prospects for men and women, employment opportunities, and government factors such as legislation and taxation. ${ }^{8}$

${ }^{3}$ It is extremely difficult to provide a generally valid definition of households. Attempts to find "a precise, reduced definition" have been unsuccessful, as households are "inherently complex, multifunctional institutions imbued with a diverse array of cultural principles and meanings". Sylvia Junko Yaganisako, "Family and Household: The Analysis of Domestic Groups", Annual Review of Anthropology, 8 (1979), pp. 161-205, 200.

4 Randall H. McGuire, Joan Smith, and William G. Martin, "Patterns of Household Structures and the World-Economy", Review, vol. 10, No. 1 (Summer 1986), pp. 75-97, 76.

3 Donald R. Bender, "A Refinement of the Concept of Household: Families, Co-Residence, and Domestic Functions", American Anthropologist, 69 (1967), pp. 493-504, 498.

- The Canadian bushworker camps in Ian Radforth's Bushworkers and Bosses: Logging in Northern Ontario, 1900-1980 (Toronto, 1987), Ch. 5, are examples of secondary households. 7 Sylvia Junko Yaganisako, "Explicating Residence: A Cultural Analysis of Changing Households among Japanese-Americans", in: Robert McC. Netting, Richard R. Wilk, and Eric J. Arnould (eds.), Households. Comparative and Historical Studies of the Domestic Group (Berkeley, Calif., 1984), pp. 330-352, 330.

"Yaganisako, "Family and Household", pp. 167-175; David J. Maume and R. Gregory Dunaway, "Determinants of the Prevalence of Mother-Only Families", Research in Social Stratification and Mobility, 8 (1989), pp. 313-327; Michael Mitterauer, "Faktoren des Wandels historischer Familienformen", in: Mitterauer, Familie und Arbeitsteilung. Historischvergleichende Studien (Vienna, 1992), pp. 214-255. 
(v) Households should not be considered anthropomorphic entities through being designated as products of collective will. Members do not necessarily work for the common good of the household; on the contrary, they may be driven by selfish motives. Conflicts of interest are also possible, as well as oppression and resistance against oppression. ${ }^{9}$ Both dependency and authority may vary according to the member of the household. Laslett pointed out that infants and children have the greatest stake in the household's survival, "since their life chances depend almost wholly on its existence and persistence, on their being accepted and retained as members. But children also have the least power to affect the household's decisions and none whatever to carry them out". ${ }^{10}$

This statement about influencing household decisions implies that while we should not arbitrarily ascribe a collective will to households, members nevertheless try to find (a variety of) ways to control their fate whenever possible. To this end, they negotiate to devise a strategy for generating and allocating the common budget.

In these negotiations, household members must take various aspects into consideration. Contrary to the assumptions of economists constructing models, ${ }^{11}$ research in social sciences and history suggests that motives are very rarely purely economic, ${ }^{12}$ but are usually based on meaningful orientations. Three of these interdependent motives keep reappearing.

First comes the need for security. Students of the working class ${ }^{13}$ have confirmed James Scott's statement that "for those at the margin, an insecure poverty is far more painful and explosive than poverty alone". ${ }^{14}$ To maximize the size and stability of their budget, members of households may pursue good employment contracts and social benefits, distribution of risks by diversifying their sources of income, and/or earning part of their income through self-employment. These circumstances justify

9 Judith Bruce, "Homes Divided", World Development, 17 (1989), pp. 979-991; Diane L. Wolf, "Daughters, Decisions and Domination: An Empirical and Conceptual Critique of Household Strategies", Development and Change, 21 (1990), pp. 43-74.

to Peter Laslett, "The Family as a Knot of Individual Interests", in: Netting, Wilk, and Arnould, Households, pp. 353-379, 370-371.

"See Gary S. Becker, A Treatise on the Family (Cambridge, Mass., 1981).

12 Richard Sennett and Jonathan Cobb convincingly argued this point of view in The Hidden Injuries of Class (New York, 1972).

${ }^{13}$ Seymour Martin Lipset, Political Man: The Sacial Bases of Politics (Garden City, N.Y., 1959), p. 232; Gaston V. Rimlinger, "The Legitimation of Protest: A Comparative Study in Labor History", Comparative Studies in Society and History, 2 (1959-1960), pp. 329-343; John C. Leggett, "Economic Insecurity and Working-Class Consciousness", American Sociological Review, 29 (1964), pp. 226-234; Maurice Zeitlin, "Economic Insecurity and the Political Attitudes of Cuban Workers", American Sociological Review, 31 (1966), pp. 35-51. ${ }^{14}$ James C. Scott, The Moral Economy of the Peasant. Rebellion and Subsistence in Southeast Asia (New Haven and London, 1976), 34. 
Rolande Trempe's observation that "The workers of Carmaux preferred to earn less as miners while continuing to do work (whether independently or for an employer) that provided for a substantial portion of their needs and provided some security against hunger during the all too frequent hard times including strikes, unemployment, and periods of deprivation or inflation." 15 A recent study of rural ties among urban workers in Enugu, Nigeria contradicts the theory of modernization by revealing how these ties have become stronger rather than weaker over the past thirty years. This tendency results from the virtual absence of a social security system covering illness, disablement, and old age, thus forcing those with low incomes to continue to rely on their villages for their security. ${ }^{16}$

The second motive for attempting to control the household budget is the drive towards dignity and respectability. People are not mere objects. Rather, their innate value is characterised by its non-negotiability. ${ }^{17}$ While social historians frequently limit discussions on respectability to the more affiuent workers of nineteenth-century England, a more general application of this term refers to Barrington Moore's "decent human treatment". ${ }^{18}$

The third motive for these household negotiations is a desire for justice, which involves the need for reciprocal relationships with other parties and may apply to "social relationships in the institutional areas of authority and social coordination, production, and distribution, or more commonly in all three". ${ }^{19}$ Expressions of this desire for equality may range from a collective struggle for emancipation through individual attempts at selfimprovement to envious behaviour designed to drag others down a notch. ${ }^{20}$

These three motives are clearly social constructs subject to various interpretations by different members of a household (especially according to differences in gender and age) and must always be viewed in terms of their specific social, economic, cultural, and political contexts. Furthermore,

1s Rolande Trempe, Les mineurs de Carmaux 1848-1914 (Paris, 1971), vol. I, p. 224.

${ }^{16}$ Josef Gugler, "Life in a Dual System Revisited: Urban-Rural Ties in Enugu, Nigeria, 1961-87", World Development, 19 (1991), pp. 399-409, esp. 405.

17 "In the realm of ends everything has either a PRICE or a DIGNIr. Whatever has a price can be replaced by something else as its equivalent. But what is raised above all price and therefore admits of no equivalent, has a dignity. [ . . ] but that which constitutes the condition under which alone something can be [an] end in itself, has not a mere relative value, that is a price, but an intrinsic value, that is dignity." Immanuel Kant, "Grundlegung zur Metaphysik der Sitten" ["Fundamental Principles of the Metaphysic of Ethics", translated by Otto Manthey-Zorn (Appleton-Century-Crofts, 1938] (1785), Werke in Sechs Banden, vol. IV (Darmstadt, 1983), p. 68.

18 Barrington Moore Jr., Injustice. The Social Bases of Obedience and Revolt (White Plains, N.Y., 1978), p. 326. Also see Elvin Hatch, "Theories of Social Honor", American Anthropologist, 91 (1989), pp. 341-353.

19 Barrington Moore, Injustice, p. 455. Cf. Godelier: "[ . . ] for relations of domination and exploitation to be formed and reproduced in a lasting fashion, they must be presented as an exchange, and as exchange of services." Maurice Godelier, The Mental and the Material, translated by Martin Thom (London, 1986), p. 160.

20 Helmut Schoeck, Der Neid. Eine Theorie der Gesellschaft (Freiburg, 1968). 
the three motives are closely intertwined. Reinhard Bendix mentioned the link between self-respect and security. ${ }^{21}$ Julian Pitt-Rivers introduced an aspect of reciprocity with his description of honour (dignity, respectability) as "an evaluation of self in the terms which are used to evaluate others or as others might be imagined to judge."22 Finally, Oskar Negt and Alexander Kluge convincingly argue that workers are also trying to act on behalf of justice when they go on strike for wage increases. ${ }^{23}$

The existence of a link between the three motives does not mean they are always in harmony with one another. Conflicts may result both from different interpretations by various members of a household and from possible cases of incongruence. Households, like individuals, may for example face a choice between respectability and economic security (if, say, members are forced to do degrading work).

\section{Income and Expenditure}

The function of social budget pooling in households entails income and expenditure. This process need not be exclusively monetary: it may also consist of goods and services.

The pattern of expenditure in independent households is composed of at least five types of expenses: ${ }^{24}$

-Support of household members involved in productive labour.

-Support of these same individuals during periods of disability or unemployment.

-Support of older household members who used to be involved in productive labour.

-Support of younger household members not yet involved in productive labour.

-Means to make payments to third parties (such as taxes, duties, and payment of debts).

This list includes the possibility of economies of scale arising from common use of certain goods. (Whether a household consists of two members or five, its members can make due with one vacuum cleaner.)

21 Reinhard Bendix, Work and Authority in Industry: Ideologies of Management in the Course of Industrialization (Berkeley, 1974), Ch. 7.

z Julian Pitt-Rivers, "Honor", Encyclopaedia of the Social Sciences, 6 (1968), pp. 503-511, 503.

23 Oskar Negt/Alexander Kluge, Geschichte und Eigensinn (Frankfurt/M., 1981), p. 604.

24 This distribution is based in part on Claude Meillassoux's three categories of reproduction costs: "The value of the work force is derived from three factors: supporting workers during periods of employment (refaining the existing work force), maintaining workers during periods of idleness (such as unemployment or illness), replacing workers by providing for their progeny (known as reproduction)." Claude Meillassoux, Femmes, Greniers \& Capitaux (Paris, 1975), p. 152. 
The income of independent households is derived from at least seven sources:2s

-Means obtained through labour remunerated in wages or in kind. - Means obtained through non-commercial labour (directly consumable goods), including homemade clothing, raising domestic animals such as pigs and poultry, ${ }^{26}$ and gathering rubbish for direct reuse. ${ }^{27}$ - Means obtained through petty commodity production or petty commerce, including manufacturing cottage-industry textiles, raising livestock for sale, peddling, ${ }^{28}$ and professional scavenging. ${ }^{29}$

- Means derived from providing resources such as land, tools for labour, accommodation, and money. These means may include income received from renting out beds or rooms. ${ }^{30}$

-Means obtained through transfer payments received without immediate reciprocal exchange of labour or commodities, including support from friends and acquaintances in times of need, charity, and social benefits.

- Means obtained from theft, including both conventional methods of stealing and, especially pilfering at the workplace. ${ }^{31}$

${ }^{25}$ Kathie Friedman listed the first five of these sources of income in "Households as IncomePooling Units", in: Joan Smith, Immanuel Wallerstein, and Hans-Dieter Evers (eds.), Households and the World-Economy (Beverly Hills, Calif., 1984) pp. 37-55, 46.

${ }^{26}$ Bettina Bradbury, "Pigs, Cows, and Boarders: Non-Wage Forms of Survival among'Montreal Families, 1861-91", Labour/Le Travailleur, 14 (Fall 1984), pp. 9-46; Béatrice Cabedoce, "Jardins ouvriers et banlieue: le bonheur au jardin?" in Alain Faure (ed.), Les Premiers Banlieusards. Aux Origines des Banlieues de Paris 1860-1940 (Paris, 1991), pp. 249-279.

27 See James R. Barrett, Work and Community in the Jungle. Chicago's Packinghouse Workers 1894-1922 (Urbana and Chicago, 1987), p. 104.

${ }^{28}$ John Benson, The Penny Capitalists. A Study of Nineteenth-Century Working Class Entrepreneurs (Dublin, 1983); Serge Jaumain, "Contribution à l'histoire comparé: les colporteurs belges et québécois au XIXe siècle", Histoire sociale/Social History, 39 (1987), pp. 49-77.

29 Alain Faure, "Classe malpropre, classe dangereuse? Quelques remarques a propos des chiffoniers parisiens au XIXe siècle et de leurs cités", Recherches, 29 (December 1977), pp. 79-102; Chris Birkbeck, "Self-Employed Proletarians in an Informal Factory: The Case of Cali's Garbage Dump", World Development, 6 (1978), pp. 1173-1185; Daniel T. Sicular, "Pockets of Peasants in Indonesian Cities: The Case of Scavengers", World Development, 19 (1991), pp. 137-161.

30 Bradbury, "Pigs, Cows, and Boarders"; John Modell and Tamara Hareven, "Urbanization and the Malleable Household: An Examination of Boarding and Lodging in American Families", Journal of Marriage and the Family, 35 (1973), pp. 467-479; Franz Briggemeier and Lutz Niethammer, "Schlafgănger, Schnapskasinos und schwerindustrielle Kolonie. Aspekte der Arbeiterwohnungsfrage im Ruhrgebiet vor dem ersten Weltkrieg", in: J. Reulecke/W. Weber (eds.), Fabrik, Familie, Feierabend. Beiträge zur Sozialgeschichte des Alltags im Industriezeitalter (Wuppertal, 1978), pp. 153-174; Josef Ehmer, "Wohnen ohne eigene Wohnung. Zur sozialen Stellung von Untermietem und Bettgehern", in: Lutz Niethammer (ed.), Wohnen in Wandel. Beitrdge zur Geschichte des Alltags in der burgerlichen Gesellschaft (Wuppertal, 1979), pp. 132-150.

${ }^{31}$ See Adrian J. Randall, "Peculiar Perquisites and Pernicious Practices. Embezzlement in the West of England Woollen Industry, c. 1750-1840", International Review of Social History, 
-Means obtained through credit, including billing in instalments, deferred payments, or pawning personal property. ${ }^{32}$

Working-class households (the major focus in this paper) entail households where the first source of income (remunerated labour) prevails in importance. This statement does not exclude the role of other sources of income. On the contrary, working-class households usually rely on a variety of sources of income, virtually all members generate some income, and individual members (especially over the course of their entire lives) tend to provide income from numerous sources. While these observations do not imply the absence of a clear correlation between age and gender on the one hand and revenue-producing activities on the other, it is likely that the degree of correlation varies according to the source of income. ${ }^{33}$

\section{Strategies for Improvement}

The satisfaction of working-class households with their material circumstances depends not only on whether their income covers basic necessities. Other significant issues include the reliability of the sources of income (the lack thereof may lead to insecurity), the question of whether this income stems from work considered undignified, and the question of whether the acquisition of income involves the acceptance of basic injustices.

All these questions determine a household's strategies for survival and improvement. I will start by examining the means for self-improvement at the disposal of individual households. First, they might move to another neighbourhood, city, or country in the hope of finding more satisfactory conditions. Millions have already chosen this option. Second, they can take advantage of better times to take precautionary measures for the hard times that lie ahead. These measures may include saving money ${ }^{34}$ or

35 (1990), pp. 193-219, and Michael Gruttner, "Working-Class Crime and the Labour Movement: Pilfering in the Hamburg Docks, 1888-1923", in: Richard J. Evans (ed.), The German Working Class 1888-1933. The Politics of Everyday Life (London and Totowa, 1982), pp. 54-79. William Freund reveals the possibility of a smooth transition to theft as a collective act in "Theft and Social Protest Among the Tin Miners of Northem Nigeria", Radical History Review, 26 (1982), pp. 68-86.

${ }^{32}$ Michelle Perrot, Les ouvriers en grève. France 1871-1890 (Paris and The Hague, 1974), vol. I, pp. 210-212; Melanie Tebbutt, Making Ends Meet. Pawnbroking and Working-Cless Credit (New York, 1983); Paul Johnson, Saving and Spending. The Working-Class Economy in Britain 1870-1939 (Oxford, 1985), Ch. 6.

33 Joan Smith and Immanuel Wallerstein, "Households as an Institution of the WorldEconomy", in Joan Smith et al., Creating and Transforming Households. The Constraints of the World-Economy (Cambridge, 1992), pp. 3-23, 11-12.

34 Gunther Schulz, "Der konnte freilich ganz anders sparen als ich'. Untersuchungen zum Sparverhalten industrieller Arbeiter im 19. Jahrhundert", in: Werner Conze and Ulrich Engelhard: (eds.), Arbeiterexistenz im 19. Jahrhundert. Lebensstandard und Lebensgestaltung deutscher Arbeiter und Handwerker (Stuttgart, 1981), pp. 487-515; Jos De Belder, "Het arbeiderssparen 1850-1890", in: August Van Put et al. (eds.), De Belgische Spaarbanken. 
purchasing a house. ${ }^{35}$ Third, households may reduce expenses through measures such as living (still more) frugally, not paying their debts, and expelling non-productive members. Fourth, they can change the way they obtain their income, for example by seeking other work or through diversification of their sources of income.

In addition to measures for households to try to improve their living conditions independently, there are several strategies involving help from outside sources. First, households may appeal to relatives. Many authors have indicated the value of kinship for household survival. Tamara Hareven wrote that to many American immigrants and urban workers, kin were

the main, if not the only, source of assistance and survival. In the absence of public welfare agencies and social security kin were the exclusive source of social insurance. Kin assistance was crucial in handling personal and family crises (such as child-bearing, illness, and death), and in coping with the insecurities imposed by the industrial system (such as unemployment, accidents, and strikes). [Furthermore ... s]trategies for kin assistance required both short-term and long-term investments over the life-course. Short-term investments entailed assistance in the workplace, in housing, in loaning money or tools, and trading skills, goods, or services. Among the long-term investments, the most pervasive exchange was that between parents and children, - old-age support in return for childrearing. ${ }^{36}$

Kinship relations outside one's immediate surroundings often proved especially important. An interesting method of distributing the risks involves mutual assistance between rural-agrarian and urban relatives. Heidi Rosenbaum described an example of this system when she mentioned the importance "of family support from relatives in the countryside" for workers in Linden (Germany) in the early twentieth century. ${ }^{37}$ Jean Peterson showed how the reverse currently holds true for Philippine peasantry by writing that "some families explicitly plan to establish some siblings $[\ldots]$ as wage-earners in the city" to generate revenue in cases of crop failure or poor harvests. ${ }^{38}$

A second source of relief lies in personal communities. These communities consist of informal networks based on companionship, emotional aid, and

Geschiedenis, Recht, Economische Funktie en Instellingen (Tielt, 1986), pp. 91-119; Johnson, Saving and Spending, Ch. 4.

${ }^{35}$ John Modell, "Changing Risks, Changing Adaptations: American Families in the Nineteenth and Twentieth Centuries", in: Alan J. Lichtman and Joan R. Challinor (eds.), Kin and Communities: Families in America (Washington, D.C., 1979), pp. 128-129; Barrett, Work and Community in the Jungle, pp. 104-107.

${ }^{36}$ Tamara K. Hareven, "A Complex Relationship: Family Strategies and the Processes of Economic and Social Change", in: Roger Friedland and A.F. Robertson (eds.), Beyond the Marketplace. Rethinking Economy and Society (New York, 1990), pp. 215-244.

"Heidi Rosenbaum, Proletarische Familien. Arbeiterfamilien und Arbeiterväter im fruhen 20. Jahrhundert zwischen traditioneller, sozialdemokratischer und kleinburgerlicher Orientierung (Frankfurt/M., 1992), p. 153.

3a Jean Treloggen Peterson, "Interhousehold Exchange and the Public Economy in Three Highland Philippine Communities", Research in Economic Anthropology, 11 (1989), pp. 123-142, 136. 
small services in daily life. While the networks may be locally based (neighbourhoods), this restriction is not essential to their operation. Personal communities also include kinship networks and require the same investment as strategies for short-term kin assistance (relatively small and readily available skills and services).$^{39}$ Personal communities have always appeared gendered, although their focus varies depending on the time, the place, and the culture. ${ }^{40}$ There is often a fluid line between blood relatives and personal communities, as proved by frequent transformations of friendships into fictitious kinship relations, such as with compadrazgo (fictitious parenthood usually involving the relationship between parents and godparents to a child) in Latin America ${ }^{41}$ and the selection of Taufpaten (godparents) among the nineteenth-century German working class. ${ }^{42}$

Acceptance of patronage is a third strategy. Whereas the first two forms of social insurance are generally horizontal, (the actors pertained to similar social classes), this approach is clearly vertical. As Y. Michal Bodemann wrote, it involves "a form of class rule and class struggle and at the same time its concealment." 43 Weak subalterns seek protection from higher, more powerful individuals who help them in emergencies in return for material or other types of services. This relationship is not merely economic but sociocultural as well, as patrons receive their clients' loyalty and esteem in return for their protection and help. Forms of patronage may vary from political clientelism to patriarchal enterprise."

A fourth and final strategy for social insurance involves joining or founding social movement organizations to bring about overall improvement in the conditions of (segments of) the working class. Examples of this strategy are mutual aid societies, producer or consumer cooperatives, trade unions, political parties, and combinations of these movements.

39 Barry Wellman, Peter J. Carrington, and Alan Hall, "Networks as Personal Communities", in: Barry Wellman/S.D. Berkowitz (eds.), Social Structures. A Network Approach (Cambridge, 1988), pp. 130-184, 163.

${ }^{40}$ Compare personal communities in London between 1870 and 1914 in Ellen Ross, "Survival Networks: Women's Neighbourhood Sharing in London Before World War I", History Workshop Journal, 15 (Spring 1983), pp. 4-27, to those in Lebanon in the 1970s in Suad Joseph, "Working-Class Women's Networks in a Sectarian State: A Political Paradox", American Esthologist, 10 (1983), pp. 1-22.

"Sidney W. Mintz and Eric R. Wolf, "An Analysis of Ritual Co-Parenthood (Compadrazgo)", Southwestern Journal of Anthropology, vol. 6, No. 4 (Winter 1950), pp. 341-368.

${ }^{21}$ Hartmut Zwahr, Zur Konstiruierung des Proletariats als Klasse. Strukturuntersuchungen uber das Leipziger Proletariat während der industriellen Revolution (Berlin, 1978), pp. 163189.

${ }^{43}$ Y. Michal Bodemann, "Relations of Production and Class Rule: The Hidden Basis of Patron-Clientage", in: Wellman and Berkowitz, Social Structures. A Network Approach, pp. 198-220, 215.

4 For a comprehensive analysis of industrial paternalism, see Alvarez Sierra, El obrero soñado. Ensayo sobre el paternalismo industrial (Asturias 1860-1917) (Madrid, 1990), pp. 7164. 
At least eight ways exist for households to improve their circumstances, whether they do so independently or with outside help. How households devise their strategy is of course crucial. Several factors come into consideration. The preceding description is taxonomic in that it covers opportunities that may arise over time. The various options are actually limited to specific historical contexts. Paternalism, for example, is less likely in advanced industrial societies than in less developed ones. ${ }^{45}$ Each actual situation will therefore present fewer opportunities than those described here. On the other hand, each strategy consists of several options: for example, those who wish to join social movement organizations can sometimes choose from a wide range of possibilities. It is also possible (and even common) to use several strategies at once. Furthermore, the strategies described here are interrelated and can alternatively undermine or reinforce one another. Frequent geographical mobility can work against the establishment of powerful unions in some cases, whereas it might actually form the basis for organizations in other cases. ${ }^{46}$ Strategies may even intermingle. Close non-kin relationships can for example be transformed into fictitious kinship relations. ${ }^{47}$ Alternatively, kinship and personal communities may provide a valuable basis for a social movement organization. ${ }^{48}$

4s Robin Theobald and Michael A. Korovkin debate historical conditions necessary for patronage in Robin Theobald, "The Decline of Patron-Client Relations in Developed Societies", Archives Européennes de Sociologie [henceforth: AES], 24 (1983), pp. 136-147; Michael A. Korovkin, "Exploitation, Cooperation, Collusion: An Enquiry into Patronage", AES, 29 (1988), pp. 105-126; Robin Theobald, "On the Survival of Patronage in Developed Societies", AES, 33 (1992), pp. 183-191.

t6 Joan Wallach Scott, The Glassworkers of Carmaux. French Craftsmen and Political Action in a Ninereenth-Century City (Cambridge, Mass., 1974), pp. 68, 83-87; Humphrey Southall, "Mobility, the Artisan Community and Popular Politics in Early Nineteenth-Century England", in: Gerry Kearns and Charles W.J. Withers (eds.), Urbanising Britain. Essays on Class and Community in the Nineteenth Century (Cambridge, 1991), pp. 103-153.

47 The discussion of personal communities provided some examples of this transformation. It may also occur with patronage - patrons and patronesses can become godfathers or godmothers respectively - or self-organizations. Emily Honig's example of female textile workers in Shanghai during the first half of the twentieth century illustrates this point: "After working together for several years, six to ten women would formalize their relationship with one another by pledging sisterhood. Once they had formed a sisterhood, the members would call cach other by kinship terms based on age: the oldest was 'Big Sister', the next oldest 'Second Sister', and so forth. [ . . . ] Often the sisterhoods functioned as an economic mutual aid society". Emily Honig, "Burning Incense, Pledging Sisterhood. Communities of Women Workers in the Shanghai Cotton Mills, 1919-1949", Signs, 10 (1984), pp. 700-714, 700-701. Better known than this case of surrogate kinship among women are the countless fraternal organizations that have sprung up in workers' movements over timc. For examples, see Mary Ann Clawson, Constructing Brotherhood. Class, Gender, and Fraternalism (Princeton, N.J., 1989).

${ }^{4}$ Sec Zwahr, Zur Konstifuierung des Proletariats. Furthermorc, Bert Altena convincingly argues that "family acquaintance played an important part" in the formation of carly working-class organizations in "The Dutch Social Democratic Workers' Party in the Province of Zceland, 1898-1920", Tijdsclirift voor Sociale Geschiedenis, 18 (1992), pp. 389-403, 401. 


\section{Conclusion}

As households clearly have countless means of survival at their disposal, the decision to join a workers movement is far less logical and obvious than is often assumed. Labour activism, in whatever form, is but one of several options.

Historical research shows that at least a portion of the working-class population is more likely to organize as workers and resist as the share of wage labour in the household budget increases. Despite increased wage dependency, the involvement of working-class households' in labour activism is always partially determined by other factors, such as the job market, labour relations, state measures, and ethnic and religious cleavages.

Perhaps an analysis of reasons behind and ways of household engagement in labour activities should begin by distinguishing between household, enterprise, and state-centred labour activism. Household-centred activism entails measures taken by wage labourers to accomplish more with the material means at their disposal without necessarily eliciting confrontations with entrepreneurs or the authorities. Mutual aid societies, which use a communal fund from several households to provide some protection in cases of unemployment, illness, old age, or death, are one example of this type of activism. Consumer cooperatives that purchase goods for several households at once are another. Enterprise-centred activism involves efforts to alter the economic balance of power between workers and entrepreneurs. Changes may occur either through battles against capitalist industry for higher wages or improved working conditions (traditionally the unions' job), or through attempts to establish and maintain producer cooperatives. Finally, state-centred activism aims to guide or obtain improvements from the state that would be impossible (or far more difficult) to arrange through household- or enterprise-centred activism. The most obvious organizational instruments for this purpose are, of course, political parties, although it is possible for other organizations to focus their efforts on the state.

Once again, these forms of activism overlap. Mutual aid societies have often become unions, and consumer cooperatives have at times become actively involved in national politics.

The gap between household history and labour history is also made clear by the lack of research on household-centred forms of labour activism. Although many view mutual aid societies and consumer cooperatives as far less heroic than parties or unions, they have nevertheless played a major role in the improvement strategies of working-class households. Bridging the analytical gap between households and workers' struggles can provide valuable new insights into labour history. 